\title{
Investigating the effects of service quality and hedonic on behavioral intentions: An empirical survey on restaurant industry
}

\author{
Seyed Hossein Mansouri ${ }^{a^{*}}$ and Abolghasem Ebrahimi ${ }^{\text {b }}$
}

${ }^{a}$ Department of Business Management, Firoozkooh Branch, Islamic Azad University, Firoozkooh, Iran

${ }^{b}$ Department of Management, Shiraz University, Iran

\section{H R O N I C L E}

\section{Article history:}

Received May 22, 2013

Received in revised format

28 August 2013

Accepted 14 September 2013

Available online

September 152013

Keywords:

Service quality

Hedonic affect

Satisfaction

Value, Loyalty

Customer complaints

\section{Introduction}

During the past few years, there have been many studies on the effect of perceived service quality on post-consumption behaviors such as customer satisfaction, customer complaint and customer loyalty. In fact, recent studies emphasize the importance of service quality, perceived value and behavioral intentions in the restaurant industry (Ha \& Jang, 2010; Chang et al. 2010; Chow et al., 2007; Olsen, 2002). In today's competitive markets, researchers generally agree that higher service quality lead to higher level of customer satisfaction, more perceived value and positive behavioral intentions (Han \& Ryu, 2007). The positive consequences of superior service quality consist of increased customer

*Corresponding author. Tel: +989191100600

E-mail address: hm_09191100600@yahoo.com (S. H. Mansouri)

C) 2013 Growing Science Ltd. All rights reserved.

doi: $10.5267 / \mathrm{j} . \mathrm{ms} 1.2013 .09 .016$

\begin{abstract}
This research proposes a comprehensive model that investigates the relationships between service quality, hedonic, perceived value and behavioral intentions. The purpose of this study is to build a better understanding of the determinants of customer satisfaction and customer loyalty throughout the restaurant services by incorporating the perceptions of hedonic effect in service delivery and outlining why and how service quality is important to customer satisfaction and customer loyalty. Respondents were chosen from three regular customers of Atawich chain restaurants in city of Tehran by using stratified random sampling method. A total of 390 questionnaires were used for data analysis. Structural equations modeling by using LISREL was performed to empirically test the relationships between the constructs of this study. Results show that both service quality and hedonic effect are importance predictors of customer satisfaction in Iranian society. In addition, results indicate that service quality and hedonic effect have positive and significant effects on perceived value. However, relationship between customer satisfaction and perceived value with attitudinal loyalty was not significant. Finally, it suggests that restaurant managers should improve their restaurant service offerings to satisfy customers. In addition, the results emphasize the significance of hedonic effect and positive emotions in creating perceived value and customer satisfaction.
\end{abstract}

(C) 2013 Growing Science Ltd. All rights reserved. 
satisfaction (Cronin \& Taylor, 1992; Chen \& Chen, 2010; Edward \& Sahadev, 2011), customer loyalty (Zeithaml et al., 1996; Barsky \& Nash, 2002), positive word of mouth (Zeithaml et al., 1996; Alexandris et al., 2002), stay more (Zeithaml et al., 1996), and pay more (Zeithaml et al., 1996; Barsky \& Nash, 2002) in consumer behavior contexts. Service quality can be defined as "the customer's judgment about overall excellence or superiority of a product of service" (Zeithaml, 1988). In an Iranian culture, restaurants are considered as common places for social gatherings and family entertainment. Food consumption in restaurants provides an experience of excitement, pleasure, celebration, and creating social relationships. Generally, purchases process can be categorized as having search, experiential and credence properties (Nelson, 1974). Specifically, restaurant and eating is by nature an experiential purchase. Customers can assess restaurant service quality accurately; hence, restaurant functional quality in delivering services is usually the primary determinant. In restaurant setting, perceptions of customer from foods and environment including physical and social are key components in determining the restaurant service quality (Jang \& Namkung, 2009; Ryu \& Han, 2010). The literature has discussed the effects of customer satisfaction and behavioral intentions (Ladhari, 2007; Han \& Back, 2006). Other studies reported a positive relationship between customer satisfaction and behavioral intentions (Bigne et al., 2005; Han \& Back, 2006, Bigne, et al. 2008).

Despite the relative importance of service quality in chain restaurants sector, academics and managers know relatively little about how the effects of restaurant service quality and hedonic effects on perceived value and customer satisfaction, which in turn, influence behavioral intentions.

The primary objective of this study is to develop an integrated conceptual model, which investigates the effect of restaurant service quality and hedonic effect on customer satisfaction, customer perceived value and behavioral intentions. In fact, by understanding customers' responses to restaurant service quality in a post-dining behavioral process, restaurant managers can gain a better understanding of how to improve their restaurant service offerings to satisfy customers.

This study is organized as follows: We first review the conceptual framework and concepts, which are associated with our study. Second, we present a conceptual model and discuss the relationships among model constructs, along with research methodology and data collection. Finally, we present the findings, discuss implications, and suggest future research directions.

\section{Conceptual framework and hypotheses}

\subsection{Perceived service quality, customer satisfaction and perceived value}

Service quality is one of the most important factors influencing on customer behavior in service settings. Higher level of service quality produces higher level of sales revenue and efficiency (Gounaris et al., 2003). In literature, service quality is usually defined as "the customer's judgment of the overall excellence or superiority of the service" (Zeithaml, 1988). In fact, it is the customer's subjective evaluation formed by comparing expectations and their perceptions of actual services (Parasuraman et al., 1985). i.e. service quality is trade-off between perceived benefits and perceived costs (Lovelock, 2000). In earlier studies, service quality has been referred as how service satisfies customers' needs or expectations (Lewis \& Mitchell, 1990; Dotchin \& Oakland, 1994). Parasuraman et al. (1988) identified five dimensions of service quality:

(1) Tangibles (facilities, equipment and appearance of staff)

(2) Reliability (ability to perform the promised service dependably and accurately)

(3) Responsiveness (willingness to help customers and provide prompt service)

(4) Assurance (knowledge and courtesy of staff and their ability to convey trust and confidence); and

(5) Empathy (caring, individualized attention the organization provides to its customers). 
Since SERVQUAL dimensions were first developed, numerous studies have applied this model to assess service quality in service-related issues. After a comprehensive review of service quality research, Asubonteng et al. (1996) found that the number of service quality dimensions varies in various industries. In restaurant setting, perceived levels of service are based on the relationship between customers and service providers, foods and environment (physical and social) quality, thus, these components are key indicators in determining the restaurant service quality (Nikolich \& Sparks, 1995; Jang \& Namkung, 2009; Ryu \& Han, 2010).

Many researchers have examined link between service quality and satisfaction. There are some empirical evidences supporting causal linkage between service quality and customer satisfaction (Hanzaee et al., 2012; Zabkar et al., 2010; Lai et al., 2009; González et al., 2007; Chow et al. 2007; Cronin et al., 2000). These researchers found that high service quality are correlated with relatively high customer satisfaction. In addition, past studies examined link between service quality and perceived value. Findings indicated that service quality had a positive and significant relationship with perceived value (Lai et al., 2009; Chen, 2008; Choi et al., 2004; Cronin et al., 2000). Based on these arguments, we test the following hypotheses:

$\mathrm{H}_{1}$ : Service quality is positively related to customer satisfaction.

$\mathrm{H}_{2}$ : Service quality is positively related to perceived value

\subsection{Hedonic affect, customer satisfaction and perceived value}

Research on personal reports of individual effective experiences illustrated two largely independent, unipolar dimensions corresponding to positive and negative effect (Jang \& Namkung, 2009). The positive and negative effect schedule is certainly one of the most widely used scales, which has been successfully employed in a variety of studies, e.g., perceived stress and health complaints, social activities, anxiety and depressive disorders, job-search behavior, and cigarette consumption (Schmukle et al., 2002). Ligas and Chaudhuri (2012) defined hedonic store feelings as the positive effect associated with pleasure that is due to the store. In addition, they suggested that positive effect is generated when cues are appraised to be in accordance with important consumer goals. In the satisfaction literature with an empirical approach, Westbrook (1987) explored the effect of emotions elicited in consumption on satisfaction, along with expectation and disconfirmation. He found that two distinct dimensions of emotions consist of positive and negative emotions influence customer satisfaction with cable television. When a customer experiences positive emotions he/she represents higher levels of satisfaction in a service encounter (Sheng et al., 2011). In addition, shopping effect was found to have a positive impact on perceived value, which in turn positively influences a consumer's consistent repeat purchase behavior (Michon et al., 2008). Tourists with positive feelings are expected to experience higher levels of value. This is because pleasure can facilitate task fulfillment and enjoyment from the shopping activity (Yuksel, 2007). Past studies indicated that positive perceptions of merchandise value lead to greater hedonic store effect where a surplus increases positive feelings toward the store (Ligas \& Chaudhuri, 2012).

$\mathrm{H}_{3}$ : Hedonic affect is positively related to customer satisfaction.

$\mathrm{H}_{4}$ : Hedonic affect is positively related to perceived value.

\subsection{Customer satisfaction, customer compliant and customer loyalty}

Many studies have been focused on customer satisfaction to identify different characteristics of satisfaction, antecedents and consequences of customer satisfaction (Oliver, 1980, 1997, 1999). Customer Satisfaction can be defined as the degree in which one believes that an experience evokes positive feelings (Chen, 2008). In this study, customer satisfaction is defined as an evaluative of 
consumption experience, based on the discrepancy between customer expectations and the actual performance perceived after consumption process. Satisfaction with a product or service can create long-term benefits for firms including positive word-of-mouth, cross-buying, customer loyalty, perceived value and willing to pay more (Fornell et al., 1996; Palmatier et al. 2006, Ladhari, 2007, Edward \& Sahadev, 2011). In addition, past studies show that customer satisfaction has an effect on the profitability of organization. For example, when customers perceive good service, each will typically tell nine to ten people, in return, customers who receive poor service will typically express their dissatisfaction to between fifteen and twenty others (Naik et al., 2010). In addition, Shin and Elliott (2001) concluded that, through satisfying customers, organizations could improve profitability by expanding their business and gaining a higher market share. In many industries, having satisfied customers also means that organization receives fewer complaints (Fornell et al. 1996; Spreng et al. 1995). Without customer complaints, firms will have limited information on the extent and nature of service failures and may not have the opportunity to engage in service recovery. Landon (1980) defined customer complaint behavior as "an expression of dissatisfaction by individual consumers (or on a consumer's behalf) to a responsible party in either the distribution channel or a complaint handling agency". In addition, Oliver (1980) noted that complaint behavior is dissatisfaction, which is caused by negative disconfirmation of purchase expectations. Researchers have shown that effective complaint handling not only enhances the likelihood of repurchase, but also that it limits the spread of potentially damaging negative word-of-mouth (Blodgett et al., 1993). Evidence suggests that bettereducated customers are more likely to volunteer complains (Goodwin \& Ross, 1990).

Customers are more likely to complain if a service is viewed as being complex, expensive or considered important, or if the service failure is serious (Blodgett \& Granbois, 1992; Bolfing, 1989). Chang et al. (2010) revealed that customer satisfaction directly and negatively influences customer compliant. Past studies found that satisfied customers usually have better post-purchasing attitudes and higher brand loyalty, while unsatisfied customers have worse post-purchasing attitudes, showing brand switching, complaints and negative word-of-mouth activities (Loudon \& Della, 1984).

The concept of customer loyalty is well understood as a combination of customers' favorable attitude and the behavior of repurchase. Loyal customers can bring enormous advantages for a company. They allow for a continuous stream of profit, reduce marketing and operating costs, increase referral, and are immune to competitors' promotion efforts (Brunner et al., 2008). Loyalty is defined as a deeply held commitment to repeat purchase of a preferred product or service consistently in the future despite situational influence and marketing effort having the potential to cause switching behavior (Oliver 1997).

Two separate loyalty concepts evolved. Namely, "brand preference" which was later referred to as attitudinal loyalty and "share of market" which was later referred to behavioral loyalty (Thiele, 2005). This bi-dimensional concept has since been combined and referred to composite loyalty (Jacoby, 1971). Loyalty in behavioral sense is measured by using repurchase probability, long-term choice probability, or switching behavior. In attitudinal sense, loyalty is operationalized as brand preference or emotional commitment. Therefore, loyalty can be measured with repurchase intention, resistance against better alternatives, price tolerance and intention to recommend the product or service (Yi \& La, 2004). In fact, attitudinal loyalty is defined as customers' willingness to build relationships with the service providers, while behavioral loyalty refers to customers' behaviors in association with repeat purchases (Chang et al., 2010). Past studies have suggested that satisfaction influences on customer loyalty, indirectly (Espejel et al., 2008; Walsh et al., 2008; Lam et al., 2004; Oliver, 1997, Mittal \& Lassar, 1998,). This arguments leads to our next research hypotheses:

$\mathrm{H}_{5}$ : Customer satisfaction is negatively related to customer compliant.

$\mathrm{H}_{6}$ : Customer satisfaction is positively related to attitudinal loyalty.

$\mathrm{H}_{7}$ : Customer satisfaction is positively related to behavioral loyalty. 


\subsection{Perceived value, customer compliant and customer loyalty}

The customer perceived value plays an essential role on a firm's competitive strategy. This concept received traction in numerous streams of marketing literature in recent years (Trasorras et al., 2009). Values are powerful forces guiding actions, attitudes, and judgments in all aspects of our everyday lives. Researchers are continually seeking a more complete understanding of consumer value (Ryu et al., 2010). Customer perceived value can be defined as the result of the personal comparison between perceived overall benefits and the perceived sacrifices or costs paid by the customer (Ryu et al., 2012). Holbrook (1994) enlarged the traditional conceptualization of experiential value to incorporate three spheres:

(1) Extrinsic versus intrinsic value;

(2) Active versus reactive value; and

(3) Self- versus other-oriented value (Keng et al., 2007).

Some studies indicate existence of some specified relationships between quality, value, satisfaction and consequence as customer loyalty, price premium, repurchase intention and positive word of mouth (Chen \& Chen, 2010). Therefore, shopping value has a relationship with increased approach behaviors when people are on holiday (Yuksel, 2007). Researchers empirically found that perceived values have a positive effect on customer loyalty in the service industry (Thuy \& Hau, 2010).

$\mathrm{H}_{8}$ : Perceived value is negatively related to customer compliant.

$\mathrm{H}_{9}$ : Perceived value is positively related to attitudinal loyalty.

$\mathrm{H}_{10}$ : Perceived value is positively related to behavioral loyalty.

\section{Research model}

Based on preceding literature, the hypothesized relationships are shown in the conceptual framework in Fig. 1, which investigates the effects of environment on emotion, satisfaction and perceived value.

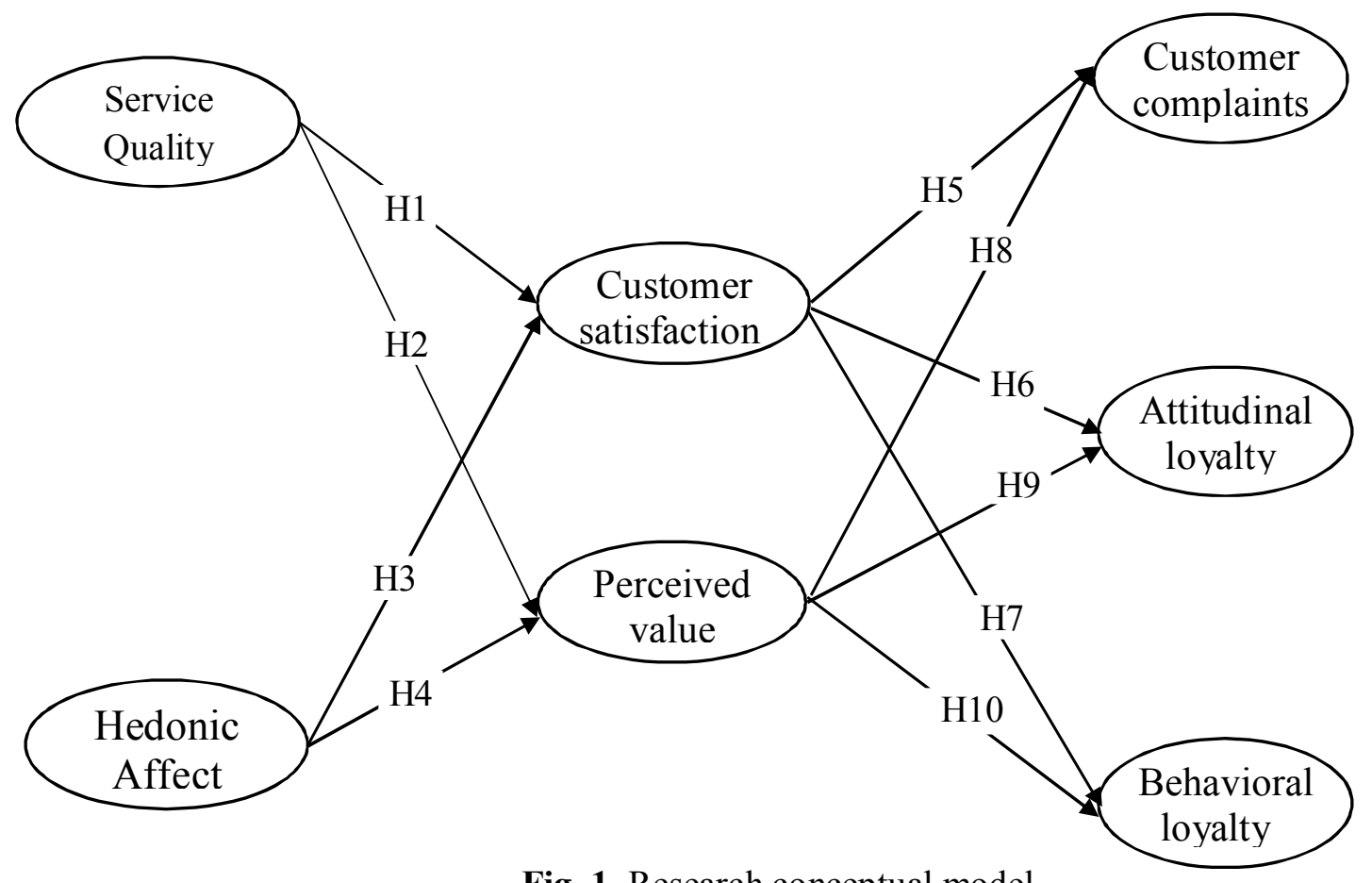

Fig. 1. Research conceptual model 


\section{Measurement items, Sample population and Data Collection Procedure}

In order to test the hypotheses empirically, multi-item scales were used to evaluate all variables to adequately capture the domain of constructs. All constructs were measured using a 5-point Likerttype scale. However, we modified the wording of specific items to reflect the focus of our investigation. Service quality was evaluated with three items extracted from the survey accomplished by Ha and Jang (2010). Value was measured using the three-item five-point Likert scale (Lasser et al., 1995; Taylor et al., 2004). Hedonic effect was measured with three items adapted from Ligas and Chaudhuri (2012). The construct of customer satisfaction includes two items adapted from Chang et al. (2010). The construct of the customer complaints regarding how customers informally or formally complain about the service they have received includes two items adapted from Chang et al. (2010). Attitudinal, loyalty was measured by using the three-item five-point Likert (Chang et al., 2010). Finally, behavioral loyalty was measured by using the four-item five-point Likert scale adapted from Chang et al. (2010).

In this research, the chain restaurants setting were selected in order to test the conceptual model and the hypothesized relationships empirically. Data were obtained from customers three Atawich chain restaurants in Tehran city. Stratified random sampling was used; however, the method of selecting respondents was random sampling. Data collected from 425 regular customers of chain restaurant and 390 usable questionnaires were retained. Fig. 1 shows demographic characteristics of the people who took part in our survey.

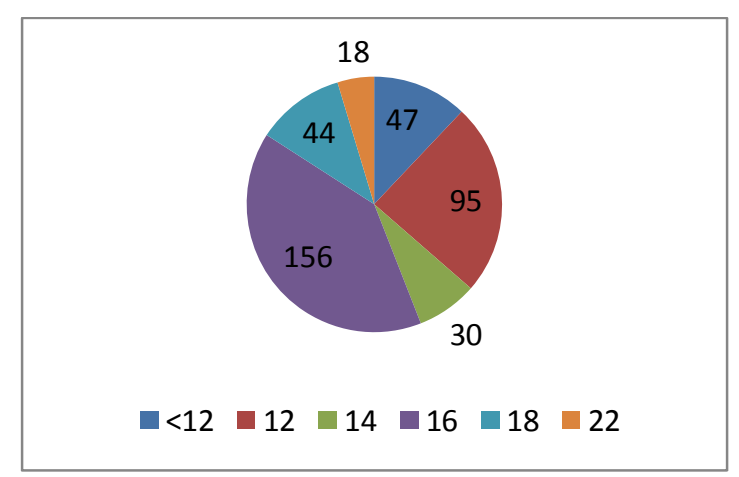

Years of education

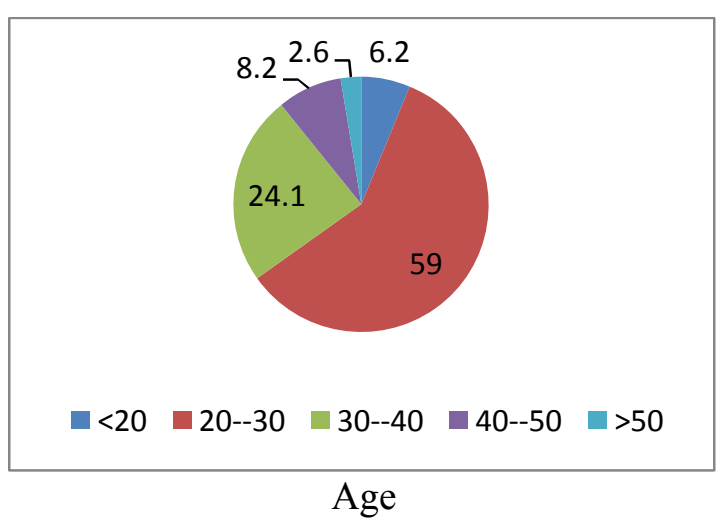

Age

Fig. 1. Personal characteristics of the participants

\section{Analysis and results}

Structural Equations Modeling (SEM) by using LISREL for Windows was performed to test the relationships between constructs in this study. In this model, as suggested by Anderson and Gerbing (1988), data were analyzed by using the two-step approach in which the measurement model was first confirmed and then the structural model was tested.

\subsection{Measurement model estimation}

Confirmatory factor analysis (CFA) was directed to examine the factor structure of the measurement model in this paper (Anderson \& Gerbing, 1988). Table 2 presents the factor loadings and Cronbach's alphas of the items on the latent constructs as estimated by the CFA. Cronbach's alphas of latent constructs were acceptable for all ten constructs $(0.72-0.88)$. Values were all above 0.70 as suggested by Nunnally (1978), and therefore indicated internal consistent. 
Table 2

Confirmatory factor analysis results

\begin{tabular}{|c|c|c|c|}
\hline Constructs & Standardized loadings & t- value & Cranach's $\alpha$ \\
\hline Service quality & & & 0.87 \\
\hline SQ 1 & 0.74 & & \\
\hline SQ 2 & 0.72 & 20.75 & \\
\hline SQ 3 & 0.70 & 20.26 & \\
\hline Hedonic affect & & & 0.84 \\
\hline HA 1 & 0.77 & & \\
\hline HA 2 & 0.76 & 24.04 & \\
\hline HA 3 & 0.79 & 24.89 & \\
\hline Customer satisfaction & & & 0.81 \\
\hline CS 1 & 0.80 & & \\
\hline $\mathrm{CS} 2$ & 0.77 & 24.18 & \\
\hline Perceived value & & & 0.78 \\
\hline PV 1 & 0.75 & & \\
\hline PV 2 & 0.75 & 22.86 & \\
\hline PV 3 & 0.78 & 23.66 & \\
\hline Customer complaints & & & 0.72 \\
\hline $\mathrm{CC} 1$ & 0.81 & & \\
\hline $\mathrm{CC} 2$ & 0.80 & 14.06 & \\
\hline Attitudinal loyalty & & & 0.83 \\
\hline AL 1 & 0.67 & & \\
\hline AL 2 & 0.63 & 17.84 & \\
\hline AL 3 & 0.69 & 19.10 & \\
\hline Behavioral loyalty & & & 0.74 \\
\hline BL 1 & 0.70 & & \\
\hline BL 2 & 0.75 & 21.16 & \\
\hline
\end{tabular}

The overall evaluation of the model fit was based on multiple indicators. These indicators included Chi-Square test; the normed fit index (NFI), the non-normed fit index (NNFI), the comparative fit index (CFI), the root mean squared error of approximation (RMSEA), the Goodness of Fit Index (GFI) and Adjusted Goodness of Fit Index (AGFI).The fit statistics showed that the measurement model fit the data reasonably well.

\subsection{Structural Model}

After assessing and confirming the total measurement model, the structural model was estimated. Results indicated an acceptable level of fit between the hypothesized model and the data. (ChiSquare $=272, \mathrm{df}=123, \mathrm{GFI}=0.93, \mathrm{AGFI}=0.90, \mathrm{NFI}=0.96, \mathrm{NNFI}=0.97, \mathrm{CFI}=0.98, \mathrm{IFI}=0.98$, $\mathrm{RFI}=0.95$ and RMSEA $=0.047)$. As predicted, service quality was positively associated with customer satisfaction (path coefficient $=0.23, \mathrm{t}=3.60$ ) and perceived value (path coefficient $=0.14, \mathrm{t}$ $=2.39$ ). Hedonic effect was positively associated with customer satisfaction (path coefficient $=0.73, \mathrm{t}$ $=11.10$ ) and perceived value (path coefficient $=0.81, \mathrm{t}=12.43$ ).

As hypothesized, customer satisfaction was negatively associated with customer complaints (path coefficient $=0.52, \mathrm{t}=-4.40$ ), But, satisfaction was not positively associated with attitudinal loyalty (path coefficient $=0.51, \mathrm{t}=0.61$ ) and behavioral loyalty (path coefficient $=0.77, \mathrm{t}=1.31$ ). However, relationship between perceived value and customer complaints was not significant (path coefficient $=$ $0.10, \mathrm{t}=0.76$ ), also the hypothesized effect of Perceived value on behavioral loyalty was not supported (path coefficient $=0.57, \mathrm{t}=0.43$ ). Nevertheless, as predicted, results show that perceived value had a positive relationship with behavioral loyalty (path coefficient $=0.63, t=7.89$ ). 
Table 3

Path estimates and hypotheses results for proposed model

\begin{tabular}{lccc}
\hline Hypothesis & Path confident & t-value & Result \\
\hline $\mathrm{H}_{1}: \mathrm{SQ} \rightarrow \mathrm{SAT}$ & 0.23 & 3.60 & Supported \\
$\mathrm{H}_{2}: \mathrm{SQ} \rightarrow$ VAL & 0.14 & 2.39 & Supported \\
$\mathrm{H}_{3}: \mathrm{HA} \rightarrow \mathrm{SAT}$ & 0.73 & 11.10 & Supported \\
$\mathrm{H}_{4}: \mathrm{HA} \rightarrow \mathrm{VAL}$ & 0.81 & 12.43 & Supported \\
$\mathrm{H}_{5}: \mathrm{SAT} \rightarrow \mathrm{COMP}$ & 0.52 & -4.40 & Supported \\
$\mathrm{H}_{6}: \mathrm{SAT} \rightarrow \mathrm{AL}$ & 0.51 & 0.61 & Not supported \\
$\mathrm{H}_{7}: \mathrm{SAT} \rightarrow \mathrm{BL}$ & 0.77 & 1.31 & Not supported \\
$\mathrm{H}_{8}: \mathrm{VAL} \rightarrow \mathrm{COMP}$ & 0.10 & 0.76 & Not supported \\
$\mathrm{H}_{9}: \mathrm{VAL} \rightarrow \mathrm{AL}$ & 0.57 & 0.43 & Not supported \\
$\mathrm{H}_{10}: \mathrm{VAL} \rightarrow \mathrm{BL}$ & 0.63 & 7.89 & Supported \\
\hline
\end{tabular}

\section{Discussion and conclusion}

Service quality is one of the most important issues in restaurant management and investigation of the effect of perceived service quality on post-consumption behaviors such as customer satisfaction, customer complaint and customer loyalty plays essential role on marketing planning. The primary objective of this study was to investigate of the effects of service quality and hedonic effects on customer satisfaction and customer loyalty in chain restaurants setting. The results clearly showed a significant role of overall restaurant service quality on perceived value and customer satisfaction.

The research findings revealed that service quality had a positive effect on customer satisfaction. The findings of this survey are consistent with Hanzaee et al. (2012); Zabkar et al. (2010); Lai et al. (2009) and Gonzalez et al. (2007). This study has also shown that service quality had a positive effect on perceived value. This result is consistent with the findings of Lai et al. (2009); Chen, (2008); Choi et al. (2004) and Cronin et al. (2000). Enhancing service quality of restaurant as a management goal as well as ensuring experience quality leading to enhance satisfaction and then perceived value, which are important issues for restaurant managers when designating their sustainability strategies. Service quality is one of the most important issues in restaurant management, because customer satisfaction is often determined by the experience obtained from quality. In this study, the role of affect in customers' postpurchase behavior has also been confirmed. As hypothesized, hedonic affect had a positive and significant relationship with customer satisfaction and perceived value. These results supported findings of Ladhari, (2007); Bigne et al. (2005); Bigne et al. (2008) and Yuksel, (2007). Overall, these results show that for experiential products or services, such as restaurant, emotions are important antecedents of satisfaction and perceived value. As predicted, customer satisfaction had a significant and negative impact on customer compliant. This result is consistent with the findings Chang et al. (2010) who reported a significant correlation and negative between customer satisfaction and customer compliant. However, the impact of satisfaction on the dimensions of loyalty was only weak. In addition, the results of this study showed that relationship between perceived value and customer compliant and attitudinal loyalty was not significant. However, the relationship between customer perceived value and behavioral loyalty was positive and significant. Value is consumer overall assessment of the utility of a product or service based on perception of what's received and what is given (Zithaml, 1988). These findings indicate that managers and service provider should seek ways in which they can reduce perceived monetary and nonmonetary costs and increase customer perceived benefits. In general, this study showed that the inclusion of service quality and hedonic effect in addition to customer satisfaction in one model not only highlights the importance of restaurant service quality and hedonic affect, but also provides a more comprehensive understanding of their effect on both customer satisfaction and perceived value.

In today's competitive environment, customers have a variety of choices for food and an extensive range of foods within the restaurant, thus the quality that a restaurant conveys may be a key 
determining factor in the decision to choose one restaurant to another one. Restaurant managers need to work very hard to keep their quality favorable in customer's mind; hence, service providers should give careful considerations to their restaurant, restaurant environment and interior design, which in turn influence the overall restaurant service quality. In addition, as a differentiation strategy, restaurant operators should develop a pleasant interior environment through effective restaurant design that will set them apart from the competition.

This research has some limitations that research findings must be considered within the limitations of the research methodology. First, our data were obtained from chain restaurant context, so the limitation in generalizability of the results is not deniable. Additional research is needed to examine these relationships within and across additional sectors. Second, in construct of behavior intention we investigate dimensions loyalty. Additional research is needed for entering new variable in study, for example, repurchase, recommendation and willing to pay more. Finally, Demographic characteristic could be also pursued in future research because customers' response to affect and service quality may be different depending upon their demographic differentiations.

\section{References}

Alexandris, K., Dimitriadis, N., \& Markata, D. (2002). Can perceptions of service quality predict behavioral intentions? An exploratory study in the hotel sector in Greece. Managing Service Quality, 12 (4), 224-231.

Anderson, J.C., \& Gerbing, D.W. (1988). Structural equation modeling in practice: A review and recommended two-step approach. Psychological Bulletin, 103(3), 411-423.

Asubonteng, P., McCleary, K.J and Swan, J.E. (1996). SERVQUAL revisited: a critical review of service quality. Journal of Services Marketing, 10 (6), 62-81.

Barsky, J., \& Nash, L. (2002). Evoking emotion. Affective keys to hotel loyalty. Cornell Hotel and Restaurant Administration Quarterly, 1, 39-46.

Bigné, J.E., A.S. Mattila and L. Andreu, (2008). The impact of experiential consumption cognitions and emotions on behavioral intentions. Journal of Services Marketing, 22(4): 303-315.

Bigné, J.E., Andreu, L and Gnoth, J. (2005). The theme park experience: an analysis of pleasure, arousal and satisfaction. Tourism Management, 26, 833-844.

Blodgett, J. G., D. H. Granbois, and R. G. Walters (1993). The Effects of Perceived Justice on Complainants Negative Word-of-Mouth Behavior and Repatronage Intentions. Journal of Retailing, 69 (4), 399-428.

Bolfing, C. (1989). How do consumers express dissatisfaction and what can service marketers do about it?. The Journal of Services Marketing, 3, 5-23.

Brunner, T. A., Stöcklin, M., \& Opwis, K. (2008). Satisfaction, image and loyalty: new versus experienced customers. European Journal of Marketing, 42(9/10), 1095-1105.

Chang, K. C., Chen, M.C., \& Hsu, C.L. (2010). Applying loss aversion to assess the effect of customers' asymmetric responses to service quality on post-dining behavioral intentions: An empirical survey in the restaurant sector. International Journal of Hospitality Management, 29, 620-631.

Chen, C.-F. (2008). Investigating structural relationships between service quality, perceived value, satisfaction, and behavioral intentions for air passengers: evidence from Taiwan. Transportation Research Part A, 42(4), 709-717.

Chen, C.F., \& Chen, F.S. (2010). Experience quality, perceived value, satisfaction and behavioral intentions for heritage tourists. Tourism Management, 31, 29-35.

Choi, K.S., Cho, W.H., Lee, S., Lee, H., \& Kim, C. (2004).The relationships among quality, value, satisfaction and behavioral intention in health care provider choice: A South Korean study. Journal of Business Resources, 57, 913-921. 
Chow, I.H., Lau, V.P., Lo, T.Y., Sha, Z., \& Yun, H. (2007). Service quality in restaurant operations in China: decision-and experiential-oriented perspectives. International Journal of Hospitality Management, 26(3), 698-710.

Cronin, J.J., \& Taylor, S.A. (1992). Measuring service quality: a reexamination and extension. Journal of Marketing, 56, 55-68.

Cronin, J.J. Jr, Brady, M.K., \& Hult, G.T.M. (2000). Assessing the effects of quality, value, and customer satisfaction on consumer behavioral intentions in service environments. Journal of Retailing, 76, 193-217.

Dotchin, J. A., \& Oakland, J. S. (1994). Total quality management in services: Part 2: Service quality. International Journal of Quality \& Reliability Management, 11, 27 - 42.

Edward, M., \& Sahadev, S. (2011). Role of switching costs in the service quality, perceived value, customer satisfaction and customer retention linkage. Asia Pacific Journal of Marketing and Logistics, 23, 327-345.

Espejel, J., Fandos, C. \& Flavian, C. (2008). Consumer satisfaction: A key factor of consumer loyalty and buying intention of a PDO food product. British Food Journal, 9, 865-881.

Fornell, C., Johnson, M. D., Anderson, E. W., Cha, J., \& Bryant, B. E. (1996). The American customer satisfaction index: nature, purpose, and findings. The Journal of Marketing, 60, 7-18.

González, M. E. A., Comesaña, L. R., \& Brea, J. A. F. (2007). Assessing tourist behavioral intentions through perceived service quality and customer satisfaction. Journal of Business Research, 60(2), 153-160.

Goodwin, C., \& Ross, I. (1990). Consumer Evaluations of Responses to Complaints: What's Fair and Why. Journal of Services Marketing, 4, 53-61.

Gounaris, S. P., Stathakopoulos, V., \& Athanassopoulos, A. D. (2003). Antecedents to perceived service quality: an exploratory study in the banking industry. International Journal of Bank Marketing, 21(4), 168-190.

Ha, J., \& Jang, S. (2010). Effects of service quality and food quality: The moderating role of atmospherics in an ethnic restaurant segment. International Journal of Hospitality Management, 29, 520-529.

Han, H., \& Back, K.J. (2007). Investigating the effects of consumption emotions on customer satisfaction and repeat visit Intentions in the lodging Industry. Journal of Hospitality Marketing \& Management, 15, 5-30.

Han, H., \& Ryu, K. (2007). Moderating role of personal characteristics in forming restaurant customers' behavioral intentions - an upscale restaurant setting. Journal of Hospitality \& Leisure Marketing, 15, 25-54.

Hnzaee, K.H., Bigdeli, F., Khanzadeh, M., \& Javanbakht, A. (2012) .Assessing patients behavioral intentions through service quality and perceived value. Journal of Basic and Applied Scientific Research, 2(10), 10686-10692.

Holbrook, M. B. (1994). The Nature of Customer Value: An Axiology of Services in the Consumption Experience, pp. 21-71 in Service Quality: New Directions in Theory and Practice, Roland T. Rust and RichardL. Oliver, (Eds.), Newbury Park, CA: Sage.

Jacoby, J. (1971). A model of multi-brand loyalty. Journal of Advertising Research, 11(3), 29 - 35.

Jang, S. S., \& Namkung, Y. (2009). Perceived quality, emotions, and behavioral intentions: Application of an extended Mehrabian-Russell model to restaurants. Journal of Business Research, 62(4), 451-460.

Keng, C.J., Huang, T.L., Zheng, L.J., \& Hsu, M.K. (2007). Modeling service encounters and customer experiential value in retailing. International Journal of Service Industry Management, $18,349-67$.

Ladhari, L. (2007).The effect of consumption emotion on satisfaction and word of mouth communication. Psychology \& Marketing, 24(12), 1085-1108.

Lai, F., Griffin, M., \& Babin, B,J. (2009). How quality, value, image, and satisfaction create loyalty at a Chinese telecom. Journal of Business Research, 62, 980-986. 
Lam, S.Y., Shankar, V., Erramilli, M.K. \& Murthy, B. (2004). Customer value, satisfaction, loyalty, and switching costs: An Illustration from a business-to-business service context. Journal of the Academy of Marketing Science, 3, 293-311.

Landon, E. L. (1980). The direction of consumer complaint research. Advances in Consumer Research, 7, 335-38.

Laros, F. J. M., \& Steenkamp, J. B. E. M. (2004). Emotions in consumer behavior: a hierarchical approach. Journal of Business Research, 58(October), 1437-1445.

Lassar, W., Mittal, B., \& Sharma, A. (1995). Measuring customer-based brand equity. Journal of consumer marketing, 12(4), 11-19.

Lewis, B.R., \& Mitchell, V.W. (1990). Defining and measuring the quality of customer service. Marketing Intelligence \& Planning, 8, $11-17$.

Ligas, M., \& Chaudhuri, A. (2012). The moderating roles of shopper experience and store type on the relationship between perceived merchandise value and willingness to pay a higher price. Journal of Retailing and Consumer Services, 19, 249-258.

Loudon, D.L., \& Della, B.A.J. (1984). Consumer Behavior-Concepts and Applications. McGrawHill, New York.

Lovelock, C.H. (2000). Service Marketing, fourth ed. Prentice Hall International.

Michon, R., Yu, H., Smith, D., \& Chebat J. C. (2008). The influence of mall environment on female fashion shoppers' value and behavior. Journal of Fashion Marketing and Management, 12, 456 468.

Mittal, B., \& Lassar, W M. (1998). Why do customers switch? The dynamics of satisfaction versus loyalty. Journal of Services Marketing, 12, 177-194.

Naik, C.N., Gantasala, S.B., \& Prabhakar, G.V. (2010). Service quality (Servqual) and its effect on customer satisfaction in retailing. European Journal of Social Sciences, 16, 231-243.

Nelson, P. (1974). Advertising as information. Journal of Political Economy, 82, 729-54.

Nikolich, M.A., \& Sparks, B.A. (1995). The hospitality service encounter: the role of communication. Journal of Hospitality and Tourism Research, 19 (2), 43-56.

Nunnally, J.C. (1978). Psychometric Theory. McGraw-Hill, New York, NY.

Oliver, R.L. (1997). Satisfaction: A behavioral perspective on the consumer. New York: McGraw Hill.

Oliver, R.L. (1993). Cognitive, affective and attribute bases of the satisfaction response. Journal of Consumer Research, 20, 418-30.

Oliver, R.L. (1999). Whence consumer loyalty? Journal of Marketing, Special Issue, 63, 33-44.

Olsen, S. O. (2002). Comparative evaluation and the relationship between quality, satisfaction, and repurchase loyalty. Journal of the Academy of Marketing Science, 30(3), 240-249.

Palmatier, R.W., Dant, R.P., Grewal, D., \& Evans, K.R. (2006). Factors influencing the effectiveness of relationship marketing: A meta analysis. Journal of Marketing, 70(3), 136-153.

Parasuraman, A., Zeithaml, V. A., \& Berry, L. L. (1985). A conceptual model of service quality and its implications for future research. The Journal of Marketing, 41-50.

Parasuraman, A., Zeithaml, V.A., \& Berry, L.L. (1988). SERVQUAL: a multiple item scale for measuring consumer perceptions of service quality. Journal of Retailing, 64 (1), 14-40.

Russell, J. A. (1980). A circumplex model of affect. Journal of Personality and Social Psychology, $39,1161-178$.

Ryu, K., \& Han, H. (2010). Influence of the quality of food, service, and physical environment on customer satisfaction in quick-casual restaurants: moderating role of perceived price. Journal of Hospitality \& Tourism Research, 34, 310-29.

Ryu, K., Lee, H. R., \& Kim, W. G. (2012). The influence of the quality of the physical environment, food, and service on restaurant image, customer perceived value, customer satisfaction, and behavioral intentions. International Journal of Contemporary Hospitality Management, 24(2), 200-223. 
Ryu, K., Han, H., \& Jang, S. (2010). The effect of hedonic and utilitarian values on customers' satisfaction and behavioral intention in the fast-casual restaurant industry. International Journal of Contemporary Hospitality Management, 22, 416-32.

Schmukle, S. C., Egloff, B., \& Burns, L. R. (2002). The relationship between positive and negative affect in the Positive and Negative Affect Schedule.Journal of Research in Personality, 36(5), 463-475.

Lin, J. S. C., \& Liang, H. Y. (2011). The influence of service environments on customer emotion and service outcomes. Managing Service Quality, 21(4), 350-372.

Shin, D., \& Elliott, K.M. (2001). Measuring customers' overall satisfaction: A multi-attributes assessment. Services Marketing Quarterly, 22 (1), 3-19.

Spreng, R. A., Harrell, G. D., \& Mackoy, R. D. (1995). Service recovery: impact on satisfaction and intentions. Journal of Services Marketing, 9(1), 15-23.

Taylor, S.A., Celuch, K., \& Goodwin, S. (2004). The importance of brand equity to customer loyalty. Journal of Product \& Brand Management, 13, 217-227.

Thiele, S.R. (2005). Exploring loyal qualities: assessing survey-based loyalty measures. Journal of Services Marketing, 7, 492-500.

Thuy, P.N., \& Hau, L.N. (2010). Service personal values and customer loyalty: A study of banking services in a transitional economy. International Journal of Bank Marketing, 28, 465 - 478.

Trasorras, R., Weinstein, A., \& Abratt, R. (2009). Value, satisfaction, loyalty and retention in professional services. Marketing Intelligence \& Planning, 27, 615 - 632.

Walsh, G., Evanschitzky, H. \& Wunderlich, M. (2008). Identification and analysis of moderator variables, Investigating the customer satisfaction-loyalty link. European Journal of Marketing, 9(10), 977-1004.

Westbrook, R.A. (1987). Product/consumption-based affective responses and postpurchase processes. Journal of Marketing Research, 24, 258-70.

Yi, Y. \& La, S. (2004). What influences the relationship between customer satisfaction and repurchase intention? Investigating the effects of adjusted expectations and customer loyalty. Psychology \& Marketing, 5, 351-373.

Yuksel, A. (2007). Tourist shopping habitat: Effects on emotions, shopping value and behaviors. Tourism Management, 28, 58-69.

Zabkar,V., Brencic, M.M., \& Dmitrovic, T. (2010). Modeling perceived quality, visitor satisfaction and behavioral intentions at the destination level. Tourism Management, 3, 1537-546.

Zeitham, V.A., Berry, L.L., \& Parasuranam, A. (1996). The behavioral consequences of service quality. Journal of Marketing, 60, 31-46.

Zeithaml, V.A. (1988). Consumer perceptions of price, quality, and value: a means-end model and synthesis of evidence. Journal of Marketing, 52, 12- 22. 